\title{
STRATEGI PENERJEMAHAN NAMA DIRI DAN KECENDERUNGAN IDEOLOGI DALAM VERSI TERJEMAHAN NOVEL ANIMAL FARM KARYA GEORGE ORWELL
}

\author{
Ina Mina Saroh \\ inaminasaroh@mail.ugm.ac.id \\ Universitas Gadjah Mada, Yogyakarta
}

\begin{abstract}
Abstrak: This paper aims to identify strategies for translating self-names (proper nouns) and ideological tendencies in translation works. The data sources used were the translated novel entitled Binatangisme (translated by Mahbub Djunaidi) as the source text and the English novel entitled Animal Farm by George Orwell as the source text. This research used the theory designed by Davies (2003) to identify translation strategies and ideological tendencies. According to Davies, there are seven translation strategies, namely preservation, addition, localization, omission, globalization, transformation and creation. The result obtained is that the translated version tends to domestication ideology. Of the 15 data analyzed, Mahbub Djunaidi's translated version has $46.67 \%$ tendencies of domestication ideology and $40 \%$ tendencies of foreignization ideology (the number is not $100 \%$ because some data using omission are considered neutral and not counted).
\end{abstract}

Keywords: Animal Farm, domestication, proper nouns, foreignization, translation strategy

Peradaban manusia ditopang oleh banyak pilar. Salah satu pilar itu bernama sastra. Sastra beredar di sudut-sudut dunia, menembus banyak kepala dan jiwa, dengan berbagai bahasa. Karenanya, bisa dikatakan bahwa kehidupan manusia yang terpotret dalam banyak karya sastra bisa dibaca dan dirasa dengan bahasa. Menurut Parera (1991:7), bahasa adalah isyarat komunikasi yang bersifat manusiawi. Berbeda dengan isyarat komunikasi hewan yang bersifat statis (dan oleh karenanya tidak dapat disebut bahasa), isyarat komunikasi manusia bersifat "produktif, imanen, dan kreatif". Dengan kata lain, bahasa bersifat dinamis. Sebagai isyarat komunikasi antarmanusia di berbagai belahan bumi, bahasa, terutama yang digunakan dalam karya-karya sastra, merupakan jembatan untuk memahami kebudayaan manusia di berbagai negara.

Munaf dkk. (2001:3) mengatakan, "Bahasa dan budaya ibarat dua sisi dari satu mata uang. Di satu sisi, bahasa merupakan alat perekam dan penyebar budaya. Di sisi lain, bahasa merupakan salah satu bentuk, aspek, dan unsur budaya." Oleh karena itu, 
bisa dikatakan bahwa bahasa merupakan produk budaya, tapi budaya tidak mungkin bisa tercipta dan berkembang tanpa adanya bahasa. Hal ini sejalan dengan pernyataan Levi Strauss (1963, dalam Sasongko, 2003) bahwa hubungan antara bahasa dan budaya bisa dilihat dari tiga sisi, yaitu (1) bahasa adalah refleksi budaya masyarakat; (2) bahasa merupakan bagian dari budaya; dan (3) bahasa mendahului budaya secara diakronis karena manusia mengetahui budaya melalui bahasa.

Satu kerja penting untuk mengalihbahasakan karya-karya sastra yang membabar kisah manusia dalam berbagai budaya disebut penerjemahan. Menurut Catford (1965), penerjemahan adalah pemindahan materi tekstual dalam satu bahasa dengan materi tekstual yang sepadan dalam bahasa lain. Masalah kesepadanan ini memang kompleks, Catford belum menyebutkan variabel budaya yang seharusnya penting untuk dipertimbangkan dalam mencari kesepadanan makna. Brislin (1976) juga mengatakan bahwa penerjemahan hanyalah memindahkan satu pemikiran atau gagasan dari satu bahasa ke bahasa lain. Sedikit berbeda dengan Catford dan Brislin, Nida dan Taber (1969) mendefiniskan penerjemahan sebagai upaya mereproduksi pesan dalam bahasa sumber ke dalam bahasa penerima dengan kesepadanan yang paling dekat dan alamiah (the closest natural equivalent), baik dalam hal makna maupun gaya. Meski kata 'budaya' tidak disebut, frasa the closest natural equivalent sudah mengindikasikan bahwa aspek budaya juga diperhitungkan oleh Nida dan Taber.

Mengingat pentingnya aspek budaya dalam penerjemahan, seorang penerjemah setidaknya harus menguasai dua bahasa dan dua budaya yang terkait dengan apa yang diterjemahkannya. Menguasai dua bahasa berarti memahami sistem dan struktur kedua bahasa, sedangkan menguasai dua budaya berarti mengetahui apa saja yang membangun dua budaya tersebut dan mampu menghadapi kendala yang muncul karena perbedaan keduanya. Kendala ini terjadi ketika penerjemah tidak menemukan padanan kata dari bahasa sumber ke bahasa sasaran. Baker (2018:19-24) menyebut kendala tersebut sebagai common problems of non-equivalence, yang meliputi:

Culture specific concepts, the source-language concept is not lexicalized in the target language, the source-language word is semantically difficult, the source and target languages make different distinctions in meaning, the target language lacks a superordinate, the target language lacks a specific term (hyponym), 
Ina Mina Saroh, Strategi Penerjemahan Nama Diri dan Kecenderungan Ideologi dalam Versi Terjemahan Novel Animal Farm Karya George Orwell

differences in physical or interpersonal perspective, differences in expressive meaning, differences in form, differences in frequency and purpose in using specific forms, and the use of loan words in the source text.

Untuk mengatasi berbagai kendala tersebut, penerjemah harus menentukan orientasi terjemahannya, yaitu apakah ke bahasa sumber atau ke bahasa sasaran. Venuti (2008:15) menyebut kedua orientasi tersebut sebagai ideologi domestikasi (domestication) dan pengasingan (foreignization). Domestikasi adalah reduksi etnosentrik dari teks asing ke dalam bahasa sasaran dengan mempertimbangkan nilainilai budaya dengan "membawa penulis ke dunia pembaca", sedangkan pengasingan memberikan pemaksaan pengakuan pada nilai-nilai budaya sumber sehingga perbedaan linguistik dan budaya teks asing diterima dengan "membawa pembaca ke dunia penulis" (Venuti, 2008:15).

Kecenderungan ideologi penerjemah bisa terbaca dengan melihat metode penerjemahan yang digunakannya. Jika mengutamakan bahasa sumber (SL/source language), maka penerjemah akan menggunakan metode word-for-word translation, literal translation, faithful translation, dan semantic translation (Newmark, 1988:45). Sementara itu, metode adaptation, free translation, idiomatic translation, communicative translation dipilih jika penerjemah berorientasi pada bahasa sasaran (Newmark, 1988:45). Newmark menyusun klasifikasi tersebut dalam sebuah diagram yang disebut diagram V sebagai berikut:

SL emphasis

Word-for-word translation

Literal translation

Faithful translation

Semantic translation
TL emphasis

Adaptation

Free translation

Idiomatic translation

Communicative translation

Gambar 1. Diagram V

Sumber: Newmark (1984)

Selain Newmark, Davies (2003:65-100) juga mempunyai teori tentang ideologi pengasingan dan domestikasi. Akan tetapi, kecenderungan tersebut dinilai dari tujuh strategi penerjemahan, yaitu preservation, addition, omission, globalization, 
localization, transformation, dan creation, untuk menganalisis nama diri (proper nouns) dalam buku-buku terjemahan.

Dengan menggunakan kategorisasi strategi penerjemahan dalam kontinum antara ideologi domestikasi dan pengasingan menurut Davies (2003), dua versi terjemahan novel Animal Farm karya George Orwell menarik untuk diteliti. George Orwell, yang bernama asli Eric Blair, merupakan penulis satire berkebangsaan Inggris yang terkenal dengan kisah-kisah petualangan dalam berbagai karyanya. Animal Farm adalah novel yang dikatakan paling mengangkat namanya selain novel 1984. Meski awalnya sempat dianggap sebagai cerita dongeng binatang, novel ini akhirnya diakui sebagai buku satire modern yang berisi sindiran halus untuk pemerintahan otoriter di Eropa saat itu.

Dalam konteks penerjemahan novel Animal Farm karya George Orwell, ada banyak versi terjemahan yang diterbitkan di Indonesia. Novel ini pertama kali diterbitkan pada tahun 1945 dan disalin pertama kali ke dalam bahasa Indonesia pada tahun 1963 oleh Joesoef Sou'yb, seorang penulis dari Medan. Terjemahan tersebut lalu diterbitkan dengan judul Kisah Pertanian Hewan oleh Seminar, sebuah badan penerbit di Medan. Pada tahun 1983, Mahbub Djunaidi menerjemahkannya lagi dengan judul Binatangisme, yang kemudian diterbitkan oleh Penerbit Iqra, Bandung. Saat itu, rezim Orde Baru masih berkuasa dan terjemahan Mahbub menjadi karya yang menyulut api perlawanan para pembacanya terhadap penguasa otoriter. Pascareformasi, novel ini diterjemahkan ulang setidaknya oleh tiga penerbit, salah satunya oleh Penerbit Bentang dengan Bakdi Soemanto (2015) sebagai penerjemahnya, dengan judul aslinya Animal Farm. Judul Binatangisme oleh Mahbub tidak digunakan lagi karena dianggap "lebih aman”. Selanjutnya, Penerbit Gading menerbitkan lagi versi terjemahan Mahbub Djunaidi dengan pertimbangan bahwa Mahbub bukan penerjemah yang patuh kepada bahasa sumber, tapi pemaknaannya memikat dan masih relevan dengan situasi terkini (Orwell, 2019:v-vi).

Karya terjemahan Animal Farm dalam bahasa Indonesia tersebut berbeda dalam hal kecenderungan ideologi penerjemah. Misalnya, ada kalimat tambahan di dalam versi terjemahan pada paragraf dua, "Malam pun berjalan sebagaimana mestinya." Karenanya, perbandingan metode penerjemahan yang digunakan di dalamnya perlu 
Ina Mina Saroh, Strategi Penerjemahan Nama Diri dan Kecenderungan Ideologi dalam Versi Terjemahan Novel Animal Farm Karya George Orwell

dilakukan untuk mengetahui kecenderungan ideologi penerjemah yang notabene merupakan sastrawan berpengaruh pada masanya. Mahbub Djunaidi adalah sastrawan sekaligus esais yang karya-karyanya sering kali filosofis dan kritis tapi juga kadang humoris. Oleh karena itu, penelitian ini berfokus pada satu permasalahan, yaitu strategi penerjemahan nama diri apa saja yang memengaruhi kecenderungan ideologi penerjemah dalam menerjemahkan novel Animal Farm? Dalam hal ini, Xiao-Jiang Yan (2007) berkata, "Since each text is produced for a given purpose and should serve this purpose, it is crucial for the translator to know why text is translated and what the function of the translated text."

Penelitian tentang terjemahan novel Animal Farm telah banyak dilakukan, misalnya oleh Husnul Abdi dan Aris Munandar (2019) yang berjudul The Translation of Idioms in George Orwell's Animal Farm. Terjemahan yang digunakan adalah karya Bakdi Soemanto, dan idiom-idiom yang ditemukan pada teks asli diklasifikasikan berdasarkan klasifikasi idiom Adam Makkai (1972). Strategi penerjemahan idiom diidentifikasi dengan membandingkan idiom-idiom pada teks sumber dengan terjemahan pada teks sasaran. Dengan menggunakan terjemahan Bakdi Soemanto, Azwar Arif (2017) juga meneliti novel Animal Farm. Arif berfokus pada terjemahan satirenya dan menggunakan konsep satire Keraf (2006) untuk menganalisis unsurunsur ungkapan satire di dalamnya. Metode teknik terjemahan diteliti berdasarkan teori Molina dan Albir (2002).

Umar Mono (2015) dalam disertasinya yang berjudul Padanan Makna Budaya dalam Karya Sastra: Kajian Kasus Terjemahan Novel Animal Farm dalam Bahasa Indonesia melakukan penelitian dengan menggunakan versi terjemahan Mahbub Djunaidi yang berjudul Peternakan Binatang. Data penelitiannya berupa kata, frasa, dan klausa yang mengandung istilah budaya berdasarkan konsep Newmark (1988). Selain bertujuan untuk mengidentifikasi kategori makna budaya dan variasi padanannya, penelitian ini juga berupaya mengungkapkan tipologi padanan terjemahan makna budaya, strategi penerjemahan, gambaran pergeseran, dan faktor penyebab terjadinya pergeseran. 
Dua karya terjemahan Animal Farm versi Bakdi Soemanto dan Mahbub Djunaidi pernah diteliti oleh Amalia Anisa Fitri (2017). Penelitian ini bertujuan untuk menemukan perbedaan dan persamaan jenis idiom dalam dua versi terjemahan tersebut dengan menggunakan teori Fernando tentang jenis idiom bahasa Inggris, teori Chaer tentang jenis idiom bahasa Indonesia, dan teori Mona Baker tentang strategi penerjemahan idiom. Ideologi penerjemahan sama sekali tidak dibahas dalam penelitian ini.

Penelitian tentang kecenderungan ideologi domestikasi dan pengasingan sudah banyak dilakukan, tapi sumber datanya bukan novel Animal Farm. Misalnya, Obeidat dan Abu-Melhim (2017) melakukan penelitian yang berjudul Foreignization and Domestication in Translating English-Arabic Baby Formula Labels dan menemukan bahwa pengasingan ditandai dengan penggunaan metode literal translation, transliteration, borrowing, dan transference. Sementara itu, domestikasi dilakukan dengan transposition, omission, addition, dan adaptation.

Dewi Laraswaty (2014) juga menganalisis domestikasi dan pengasingan penerjemahan istilah budaya di novel Laskar Pelangi karya Andrea Hirata dengan menggunakan teori Tomalin dan Stempleski (1993) yang mengategorikan istilah budaya ke dalam ideas (values, beliefs, institutions), products (customs, habits, food, dress, lifestyles), dan behaviors (folklore, music, art, literature). Hasil penelitian menunjukkan bahwa penerjemah cenderung menggunakan ideologi domestikasi ketika menerjemahkan novel ini ke dalam bahasa Inggris.

Kecenderungan ideologi juga diteliti oleh Erys Shandra (2014) pada novel Harry Potter and the Sorcerer's Stone karya Joanne K. Rowling yang diterjemahkan menjadi Harry Potter dan Batu Bertuah oleh Listiana Srisanti. Penelitian ini berfokus pada identifikasi teknik penerjemahan nama diri berdasarkan teori Davies (2003) tentang tujuh teknik penerjemahan, yaitu preservation, addition, localization, omission, globalization, transformation, dan creation. Sebagian hasil penelitian menunjukkan bahwa ideologi pengasingan diindikasikan oleh dua teknik, yaitu preservation dan addition, sedangkan localization, omission, globalization, transformation, dan creation 
Ina Mina Saroh, Strategi Penerjemahan Nama Diri dan Kecenderungan Ideologi dalam Versi Terjemahan Novel Animal Farm Karya George Orwell

berada di bawah ideologi domestikasi. Persentase penggunaan teknik-teknik tersebut mengindikasikan kecenderungan penerjemah terhadap ideologi pengasingan.

Andy Bayu Nugroho dan Johnny Prasetyo (2009) melakukan kajian pustaka yang berjudul Domestikasi dan Foreignisasi dan Dampaknya terhadap Penerjemahan. Kajian ini mengungkapkan bahwa seorang penerjemah harus menguasai minimal dua bahasa (bilingual) atau lebih (multilingual) serta mampu mengatasi dampaknya terhadap penerjemahan. Masalah utama dalam menerjemahkan teks pada umumnya terkait dengan perbedaan budaya antara dua bahasa. Strategi penerjemahan untuk mengatasi masalah tersebut ditentukan oleh ideologi penerjemahnya: apakah berorientasi pada bahasa sasaran (domestikasi) atau teks sumber (pengasingan). Seorang penerjemah harus menentukan apakah ia cenderung kepada kebutuhan pembaca atau lebih mementingkan atmosfer budaya teks sumber dan ideologi penulisnya. Tidak ada sumber data yang spesifik dalam penelitian ini.

Penelitian tentang strategi penerjemahan nama diri sudah banyak dilakukan, tapi tidak ada yang menggunakan novel Animal Farm sebagai sumber datanya. Weni Ratnasari, Issy Yuliasri, dan Rudi Hartono (2016) meneliti tentang teknik dan ideologi penerjemahan vokatif (vocatives) dan nama diri (proper names) di The Hobbit. Para peneliti tersebut menemukan bahwa penerjemah menggunakan teknik penerjemahan vokatif berupa copy dan literal translation yang memiliki kecenderungan sebanyak 65,62\% kepada ideologi pengasingan serta teknik discursive creation, reduction, addition, generalization, established equivalent, deletion, dan transposition yang $34,37 \%$ cenderung kepada ideologi domestikasi.

Yunita Suryarini (2016) juga meneliti penerjemahan nama diri dalam terjemahan novel Negeri Lima Menara karya Anwar Fuadi dalam bahasa Inggris. Nama diri yang paling banyak digunakan dalam terjemahan novel tersebut, yang berjudul The Land of Five Towers, adalah personal names dengan 37,54 \% penggunaan. Persentase tersebut menunjukkan bahwa Fuadi menggunakan banyak karakter di dalam novelnya. Teknik penerjemahan yang digunakan adalah rendition, copy, transcription, recreation, substitution, deletion, addition, transposition, phonological replacement, dan 
conventionality. Copy adalah teknik yang paling sering digunakan dengan persentase 56,60\%. Dari 666 data, 613 nama diri diterjemahkan dengan padanan yang tepat.

Selain itu, Evelina Jaleniauskienė dan Vilma Čičelytė (2009) juga meneliti nama diri dalam kesusastraan anak Lithuania dengan menggunakan teori dari Eirlys E. Davies tentang strategi penerjemahan. Empat buku fantasi populer yang diterjemahkan dari bahasa Inggris dan bahasa Jerman oleh tiga penerjemah Lithuania menjadi sumber data. Setelah keempatnya diteliti, diperoleh kesimpulan bahwa strategi localization paling sering digunakan dibandingkan preservation, transformation, dan creation.

Andy Bayu Nugroho (2015) meneliti strategi penerjemahan nama diri dalam American Indian Mithology karya Evelyn Wolfson yang diterjemahkan oleh para mahasiswa Prodi Bahasa dan Sastra Inggris Fakultas Bahasa dan Seni, Universitas Negeri Yogyakarta. Sumber data kedua berupa informasi dari para penerjemah yang didapatkan melalui wawancara untuk mengungkap faktor-faktor yang memengaruhi mahasiswa dalam pengambilan keputusan untuk menggunakan strategi tertentu. Hasil dari penelitian ini adalah bahwa penerjemah menggunakan strategi copy, rendition, addition, deletion, conventionality, transposition, dan combination of copy, addition, dan rendition. Copy dan rendition paling sering digunakan. Strategi dipilih para penerjemah dengan mempertimbangkan makna semantik, semiotik, dan simbolik.

Berdasarkan tinjauan pustaka terhadap penelitian yang terkait dengan topik strategi penerjemahan nama diri kaitannya dengan ideologi domestikasi dan pengasingan atau yang menggunakan novel Animal Farm sebagai sumber datanya, dapat disimpulkan bahwa belum pernah ada penelitian yang berfokus pada strategi penerjemahan nama diri (proper nouns) dan kecenderungan ideologi penerjemahnya. Strategi penerjemahan nama diri penting untuk dilihat karena terdapat banyak tipe nama diri asing yang diterjemahkan ke dalam bahasa Indonesia. Oleh karena itu, penelitian ini penting dilakukan untuk mengapresiasi karya sastra beserta versi terjemahannya, yang lahir secara khas dengan membawa konteks zamannya masingmasing. 
Ina Mina Saroh, Strategi Penerjemahan Nama Diri dan Kecenderungan Ideologi dalam Versi Terjemahan Novel Animal Farm Karya George Orwell

\section{KAJIAN TEORETIS}

Penerjemahan harus mempertimbangkan aspek budaya dari bahasa sumber dan bahasa sasaran. Hal ini sejalan dengan definisi terjemahan menurut Nida dan Taber (1969), yaitu terjemahan melibatkan penggandaan pesan dalam bahasa sumber ke dalam bahasa sasaran dengan padanan alami terdekat dalam hal makna dan gaya. Untuk itu, seorang penerjemah harus menguasai dua bahasa, yang berarti memahami sistem dan struktur kedua bahasa, dan menguasai dua budaya, yang berarti mengetahui apa saja yang membangun dua budaya tersebut. Dengan pemahaman tentang dua budaya, penerjemah harus menentukan orientasi terjemahannya, yaitu apakah ke bahasa sumber atau ke bahasa sasaran.

Venuti (2008:15) menyebut kedua orientasi tersebut sebagai ideologi domestikasi (domestication) dan pengasingan (foreignization). Domestikasi adalah reduksi etnosentrik dari teks asing ke dalam bahasa sasaran dengan mempertimbangkan nilainilai budaya dengan "membawa penulis ke dunia pembaca". Sementara itu, pengasingan merupakan ethnodeviant pressure pada nilai-nilai budaya sehingga perbedaan linguistik dan budaya teks asing diterima dengan "membawa pembaca ke dunia penulis" (Venuti, 2008:15).

Dengan melihat metode penerjemahan yang digunakan, pembaca dapat memahami kecenderungan ideologis penerjemah. Jika prioritas diberikan pada bahasa sumber (Bsu atau bahasa sumber), maka penerjemah akan menggunakan terjemahan kata demi kata, terjemahan literal, terjemahan setia dan terjemahan semantik (Newmark, 1988: 45). Pada saat yang sama, jika terjemahan untuk bahasa sasaran, pilih metode adaptasi, terjemahan bebas, terjemahan idiomatik, dan terjemahan komunikatif (Newmark, 1988: 45).

Selain Newmark, Fernandes (2006) mengklasifikasi prosedur penerjemahan menjadi sepuluh jenis, yaitu rendition, copy, transcription, substitution, recreation, deletion, addition, transposition, phonological replacement, dan conventionality. Fernandes menggunakan istilah 'prosedur' untuk membicarakan tentang nama diri 
dalam proses penerjemahan. Prosedur dan teknik hampir sama, sehingga beberapa peneliti menyebutnya teknik penerjemahan.

Fernandes dan Davies hampir mirip. Davies (2003:65-100) juga mempunyai teori tentang ideologi pengasingan dan domestikasi. Akan tetapi, kecenderungan tersebut dinilai dari tujuh strategi penerjemahan, yaitu preservation, addition, omission, globalization, localization, transformation, dan creation, untuk menganalisis nama diri dalam buku-buku terjemahan. Berikut adalah uraian dari tiap strategi:

1. Preservation adalah stategi yang digunakan ketika seoang penerjemah mengalihbahasakan istilah dari teks sumber (selanjutnya disebut ST atau Source Text) secara langsung ke dalam teks sasaran (selanjutnya akan disebut TT atau Target Text) tanpa penjelasan apa pun. Davies mencontohkan nama "Minerva" yang tetap diterjemahkan menjadi "Minerva".

2. Addition adalah strategi yang digunakan ketika seoang penerjemah ingin mempertahankan kata aslinya tapi memberi tambahan dengan informasi apa pun yang dirasa perlu. Misalnya, Davies menunjukkan bahwa para penerjemah buku Harry Potter ke dalam bahasa Cina cenderung menjelaskan istilah-istilah dalam bahasa Inggris dengan menambahkan catatan kaki.

3. Omission adalah strategi yang berkebalikan dengan addition, yang digunakan ketika seorang penerjemah ingin membuang suatu kata atau frasa yang berpotensi membingungkan pembaca karena tidak dapat menyampaikan maknanya dalam bahasa sasaran. Strategi ini merupakan bentuk domestikasi.

4. Globalization adalah proses pengalihbahasaan sesuatu yang khas dalam budaya bahasa sumber dengan sesuatu yang lebih netral atau umum. Strategi ini seperti strategi yang diajukan Baker (1992:26-28), yaitu “translation by a more general word (superordinate)" atau "[...] a more neutral word”. Misalnya, "a Siamese cat" hanya diterjemahkan menjadi " $a$ cat".

5. Localization adalah strategi yang digunakan ketika seorang penerjemah melakukan penyesuaian fonologis dan gramatikal terhadap nama-nama dan penggunaan akhiran gender. Misalnya, ketika Virgilijus Cepaitis menerjemahkan buku Winnie-the-Pooh, nama "Christopher Robin" diterjemahkan menjadi "Kristoferis Robinas” dalam bahasa Lithuania. 
Ina Mina Saroh, Strategi Penerjemahan Nama Diri dan Kecenderungan Ideologi dalam Versi Terjemahan Novel Animal Farm Karya George Orwell

6. Transformation adalah strategi yang digunakan ketika seorang penerjemah melibatkan alterasi atau distorsi istilah yang asli. Davies memberi contoh dengan menyebut judul buku Harry Potter and the Philosopher's Stone karya J.K. Rowling yang menjadi Harry Potter and the Sorcerer's Stone dalam versi terbitan Amerika.

7. Creation adalah strategi penerjemahan dengan menciptakan istilah baru yang berbeda dari istilah yang digunakan dalam teks sumber. Menurut Davies, strategi ini jarang digunakan dan seringkali melibatkan ide kompensasi; misalnya, seorang penerjemah bisa membuang permainan kata-kata atau aliterasi di satu tempat dan menaruhnya di tempat lain dalam teks.

Davies mengilustrasikan posisi tujuh strategi penerjemahan tersebut di sepanjang kontinum antara pengasingan dan domestikasi berikut ini:



Gambar 2. Strategi Penerjemahan

[Sumber: Davies (2003:65-100)]

Strategi yang paling dekat dengan pengasingan adalah preservation karena tidak ada pengubahan apa pun dari ST ke TT. Sebaliknya, transformation dan creation paling dekat dengan ideologi domestikasi karena elemen dalam ST digantikan oleh elemen dari TT. Globalization dan omission berada di tengah-tengah antara pengasingan dan domestikasi karena sebuah elemen yang diglobalisasi atau dibuang dalam TT mengubah elemen dalam ST pada tingkatan tertentu tanpa menggantinya dengan elemen yang paralel dari TT. Addition lebih dekat ke pengasingan karena ketika 
seorang penerjemah menjelaskan elemen tertentu dalam ST, pembaca diingatkan bahwa yang dibacanya adalah teks asing. Localization, sebaliknya, lebih dekat dengan domestikasi karena penerjemah bisa memberikan sinonim dari bahasa sasaran untuk istilah dalam bahasa sumber.

Tujuh strategi penerjemahan yang dikemukakan Davies tersebut relevan dengan analisis tentang penerjemahan nama diri. Untuk itu, sebelumnya, nama diri perlu diidentifikasi. Menurut Frank (1972), ada enam tipe nama diri, yaitu personal names, geographical units, nationalities and religions, holidays, time units, dan words used for personification. Misalnya, (1) Mr. Jones untuk personal names, (2) England dan Paris untuk geographical units, (3) Indonesians dan Islam untuk nationalities and religions, (4) Christmas untuk holidays, (5) Saturday dan January untuk time units, dan (6) Liberty dan Nature untuk words used for personification-sesuatu atau abstraksi yang dianggap sebagai seseorang.

\section{METODE PENELITIAN}

Metode penelitian ini dibagi ke dalam tiga tahap, yaitu tahap pengumpulan data, tahap analisis data, dan tahap penyajian data. Data penelitian ini dikumpulkan dengan cara membaca dua teks, yaitu teks sumber berupa novel Animal Farm dalam bahasa Inggris, dan teks sasaran berupa karya terjemahan versi Mahbub Djunaidi yang berjudul Binatangisme. Karena terbatasnya lingkup penelitian ini, nama diri hanya akan dipilih dari novel ini dengan random sampling berdasarkan pertimbangan bahwa banyak terdapat nama diri yang berisi pengenalan tokoh-tokoh dan setting yang menjadi latar penulisan novel. Dari uraian itu, akan dipilih kalimat-kalimat yang mengandung nama diri sesuai kategori yang dibuat Frank (1972) dan diterjemahkan secara berbeda oleh penerjemah. Kalimat-kalimat tersebut kemudian dicatat dan diidentifikasi strategi penerjemahannya untuk kemudian diklasifikasikan berdasarkan kontinum antara pengasingan dan domestikasi yang dirancang Davies (2003).

Kalimat-kalimat yang telah diidentifikasi dan diklasifikasikan tersebut selanjutnya dianalisis berdasarkan kategori strategi penerjemahan Davies dalam kontinum antara pengasingan dan domestikasi, yaitu preservation, addition, 
Ina Mina Saroh, Strategi Penerjemahan Nama Diri dan Kecenderungan Ideologi dalam Versi Terjemahan Novel Animal Farm Karya George Orwell

localization, omission, globalization, transformation, dan creation. Setelah diklasifikasi, strategi penerjemahan tersebut dihitung frekuensi penggunaan dan persentasenya. Dengan demikian, analisis data kualitatif didukung dengan data kuantitatif.

Untuk memudahkan proses analisis, data disajikan dalam bentuk tabel-tabel data yang berisi kalimat-kalimat dari ST (novel Animal Farm dalam bahasa Inggris) dan TT (terjemahan Mahbub Djunaidi). Masing-masing tabel berisi data yang diberi nomor dengan beberapa kolom untuk memuat nomor data, teks, data, tipe nama diri, strategi penerjemahan, dan ideologi. Selanjutnya, masing-masing strategi penerjemahan akan dihitung frekuensi penggunaan dan persentasenya dalam tabel yang lain.

\section{HASIL DAN PEMBAHASAN}

Berikut ini adalah tabel yang berisi identifikasi nama diri yang dipilih secara acak dari Bab 1 novel Animal Farm beserta strategi penerjemahan, kecenderungan ideologi, frekuensi penggunaan, dan persentasenya:

Tabel 1. Temuan Strategi Penerjemahan dan Ideologinya

\begin{tabular}{|c|c|c|c|c|c|}
\hline No. & Teks & Data & $\begin{array}{c}\text { Tipe Nama } \\
\text { Diri }\end{array}$ & $\begin{array}{c}\text { Strategi } \\
\text { Penerjemahan }\end{array}$ & Ideologi \\
\hline (1) & ST & $\begin{array}{l}\text { Mr. Jones, of the Manor Farm, had } \\
\text { locked the hen-houses for the night, } \\
\text { but was too drunk to remember to shut } \\
\text { the popholes. }\end{array}$ & $\begin{array}{c}\text { personal } \\
\text { names }\end{array}$ & & \\
\hline & TT & $\begin{array}{l}\text { Tuan Jones pemilik peternakan } \\
\text { "MANOR". Malam itu ia baru saja } \\
\text { mengunci kandang ayam. Karena } \\
\text { kelewat mabuk, ia lupa menutup } \\
\text { lubang kecil tempat ayam keluar- } \\
\text { masuk. }\end{array}$ & & Localization & domestikasi \\
\hline (2) & ST & $\begin{array}{l}\text { Mr. Jones, of the Manor Farm, had } \\
\text { locked the hen-houses for the night, } \\
\text { but was too drunk to remember to shut } \\
\text { the popholes. }\end{array}$ & $\begin{array}{c}\text { geographical } \\
\text { units }\end{array}$ & & \\
\hline & TT & $\begin{array}{l}\text { Tuan Jones pemilik peternakan } \\
\text { "MANOR". Malam itu ia baru saja } \\
\text { mengunci kandang ayam. Karena } \\
\text { kelewat mabuk, ia lupa menutup } \\
\text { lubang kecil tempat ayam keluar- } \\
\text { masuk. }\end{array}$ & & localization & domestikasi \\
\hline (3) & ST & $\begin{array}{l}\text { With the ring of light from his lantern } \\
\text { dancing from side to side, he lurched } \\
\text { across the yard, kicked off his boots at } \\
\text { the back door, drew himself a last } \\
\text { glass of beer from the barrel in the } \\
\text { scullery, and made his way up to bed, }\end{array}$ & $\begin{array}{c}\text { personal } \\
\text { names }\end{array}$ & & \\
\hline
\end{tabular}


89 Lก๊TE, Volume 17 Nomor 1, Maret 2021

\begin{tabular}{|c|c|c|c|c|c|}
\hline & & $\begin{array}{l}\text { where Mrs. Jones was already } \\
\text { snoring. }\end{array}$ & & & \\
\hline & TT & $\begin{array}{l}\text { Menggenggam lampu minyak yang } \\
\text { sinarnya berayun kian-kemari, ia } \\
\text { terhuyung-huyung melintasi } \\
\text { pekarangan, menendang pintu } \\
\text { belakang rumahnya dengan sepatu } \\
\text { bot, meneguk habis gelas bir } \\
\text { penghabisan, kemudian membuang } \\
\text { diri ke tempat tidur. Nyonya Jones- } \\
\text { tentu saja istrinya-sudah lama } \\
\text { mendengkur. Bibirnya mencong, } \\
\text { setitik ingus melekat di lubang } \\
\text { hidungnya. }\end{array}$ & & Localization & domestikasi \\
\hline (4) & ST & $\begin{array}{l}\text { Word had gone round during the day } \\
\text { that old Major, the prize Middle } \\
\text { White boar, had had a strange dream } \\
\text { on the previous night and wished to } \\
\text { communicate it to the other animals. }\end{array}$ & $\begin{array}{c}\text { personal } \\
\text { names }\end{array}$ & & \\
\hline & TT & $\begin{array}{l}\text { Tersebut berita di sepanjang hari, si } \\
\text { tua bangka Major-babi putih yang } \\
\text { pernah menang kontes-punya } \\
\text { mimpi aneh di malam sebelumnya, } \\
\text { dan berniat tatap muka dengan semua } \\
\text { binatang. }\end{array}$ & & Localization & Domestikasi \\
\hline (5) & ST & $\begin{array}{l}\text { Old Major (so he was always called, } \\
\text { though the name under which he had } \\
\text { been exhibited was Willingdon } \\
\text { Beauty) was so highly regarded on } \\
\text { the farm that everyone was quite } \\
\text { ready to lose an hour's sleep in order } \\
\text { to hear what he had to say. }\end{array}$ & $\begin{array}{c}\text { personal } \\
\text { names }\end{array}$ & & \\
\hline & TT & $\begin{array}{l}\text { Si gaek major (begitulah ia selalu } \\
\text { dipanggil, walau nama ketika ikut } \\
\text { kontes Willingdon Beauty) dihormati } \\
\text { di peternakan itu, sehingga siapa saja } \\
\text { tidak keberatan rugi satu jam tidur } \\
\text { hanya untuk mendengarkan apa yang } \\
\text { tercetus dari mulutnya. }\end{array}$ & & Preservation & pengasingan \\
\hline (6) & ST & $\begin{array}{l}\text { At one end of the big barn, on a sort of } \\
\text { raised platform, Major was already } \\
\text { ensconced on his bed of straw, under } \\
\text { a lantern which hung from a beam. }\end{array}$ & $\begin{array}{c}\text { personal } \\
\text { names }\end{array}$ & & \\
\hline & TT & $\begin{array}{l}\text { Di penghujung kandang besar itu, di } \\
\text { bagian yang agak ketinggian, si babi } \\
\text { Major sudah menata diri di atas temp } \\
\text { at tidur jeraminya, persis di bawah } \\
\text { lampu gantung yang tercantel di } \\
\text { sebatang balok. }\end{array}$ & & Addition & pengasingan \\
\hline (7) & ST & $\begin{array}{l}\text { First came the three dogs, Bluebell, } \\
\text { Jessie, and Pincher, and then the } \\
\text { pigs, who settled down in the straw } \\
\text { immediately in front of the platform. }\end{array}$ & $\begin{array}{c}\text { personal } \\
\text { names }\end{array}$ & & \\
\hline & TT & $\begin{array}{l}\text { Mula-mula datang } 3 \text { anjing, Bluebell, } \\
\text { Jessie, dan Pitcher, kemudian } \\
\text { menyusul babi-babi yang segera } \\
\text { menempati tumpukan jerami, persis di } \\
\text { depan beranda kandang. }\end{array}$ & & Preservation & pengasingan \\
\hline (8) & ST & $\begin{array}{l}\text { The two cart-horses, Boxer and } \\
\text { Clover, came in together, walking } \\
\text { very slowly and setting down their } \\
\text { vast hairy hoofs with great care lest } \\
\text { there should be some small animal } \\
\text { concealed in the straw. }\end{array}$ & $\begin{array}{c}\text { personal } \\
\text { names }\end{array}$ & & \\
\hline & TT & $\begin{array}{l}\text { Dua kuda penarik kereta-Boxer dan } \\
\text { Clover-datang berbarengan, } \\
\text { melangkah gontai, berhati-hati, takut } \\
\text { kalau-kalau telapak serta kukunya } \\
\text { yang perkasa itu menginjak lumat } \\
\text { binatang yang kebetulan tersembunyi } \\
\text { di bawah jerami. }\end{array}$ & & Preservation & pengasingan \\
\hline
\end{tabular}


Ina Mina Saroh, Strategi Penerjemahan Nama Diri dan Kecenderungan Ideologi dalam Versi Terjemahan Novel Animal Farm Karya George Orwell

\begin{tabular}{|c|c|c|c|c|c|}
\hline (9) & ST & $\begin{array}{l}\text { After the horses came Muriel, the } \\
\text { white goat, and Benjamin, the } \\
\text { donkey. }\end{array}$ & $\begin{array}{l}\text { personal } \\
\text { names }\end{array}$ & & \\
\hline & TT & $\begin{array}{l}\text { Sesudah kuda, datanglah Muriel, } \\
\text { seekor domba putih, kemudian } \\
\text { Benjamin, seekor keledai. }\end{array}$ & & Preservation & pengasingan \\
\hline \multirow[t]{2}{*}{$(10)$} & ST & $\begin{array}{l}\text { Clover made a sort of wall round } \\
\text { them with her great foreleg, and the } \\
\text { ducklings nestled down inside it and } \\
\text { promptly fell asleep. }\end{array}$ & $\begin{array}{l}\text { personal } \\
\text { names }\end{array}$ & & \\
\hline & $\mathrm{TT}$ & $\begin{array}{l}\text { Si kuda Clover membentuk semacam } \\
\text { dinding dengan kaki depan mereka } \\
\text { yang besar itu, sehingga anak-anak } \\
\text { bebek itu meneriap di bagian sebelah } \\
\text { dalamnya, dan segera jatuh tertidur. }\end{array}$ & & Addition & pengasingan \\
\hline \multirow[t]{2}{*}{ (11) } & ST & $\begin{array}{l}\text { At the last moment Mollie, the } \\
\text { foolish, pretty white mare who drew } \\
\text { Mr. Jones's } \\
\text { trap, came mincing daintily in, } \\
\text { chewing at a lump of sugar. }\end{array}$ & $\begin{array}{l}\text { personal } \\
\text { names }\end{array}$ & & \\
\hline & TT & $\begin{array}{l}\text { Akhirnya, datang Mollie, kuda betina } \\
\text { putih yang cantik, penarik bendi tuan } \\
\text { Jones, melenggak-lenggok dengan } \\
\text { genitnya, seraya mengunyah } \\
\text { potongan gula. }\end{array}$ & & Omission & $\begin{array}{l}\text { antara domestikasi } \\
\text { dan foreignisasi } \\
\text { (netral; tidak } \\
\text { dihitung) }\end{array}$ \\
\hline \multirow[t]{2}{*}{$(12)$} & S T & $\begin{array}{l}\text { "Comrades, you have heard already } \\
\text { about the strange dream that I had } \\
\text { last night...." }\end{array}$ & $\begin{array}{l}\text { personal } \\
\text { names }\end{array}$ & & \\
\hline & TT & $\begin{array}{l}\text { "Sahabat-sahabat! Kalian sudah } \\
\text { dengar tentang mimpiku yang aneh } \\
\text { tadi malam...." }\end{array}$ & & transformation & Domestikasi \\
\hline \multirow[t]{2}{*}{ (13) } & ST & No animal in England is free. & $\begin{array}{c}\text { geographical } \\
\text { units }\end{array}$ & & \\
\hline & TT & $\begin{array}{l}\text { Tak ada binatang di Inggris yang } \\
\text { merdeka! }\end{array}$ & & Localization & Domestikasi \\
\hline \multirow[t]{2}{*}{$(14)$} & ST & It is called Beasts of England. & $\begin{array}{l}\text { geographical } \\
\text { units }\end{array}$ & & \\
\hline & TT & $\begin{array}{l}\text { Lagu itu bernama "BINATANG- } \\
\text { BINATANG INGGRIS". }\end{array}$ & & Localization & Domestikasi \\
\hline \multirow[t]{2}{*}{ (15) } & ST & Bright will shine the fields of England, & $\begin{array}{l}\text { geographical } \\
\text { units }\end{array}$ & & \\
\hline & TT & Mentari akan bersinar di Inggris Raya & & Omission & $\begin{array}{l}\text { antara domestikasi } \\
\text { dan pengasingan } \\
\text { (netral; tidak } \\
\text { dihitung) }\end{array}$ \\
\hline
\end{tabular}

Tabel 2. Temuan Ideologi Penerjemahan

\begin{tabular}{|c|c|c|c|c|c|}
\hline \multirow[t]{3}{*}{ Teks } & \multirow{3}{*}{$\begin{array}{c}\text { Strategi } \\
\text { Penerjemahan }\end{array}$} & \multicolumn{4}{|c|}{ Ideologi } \\
\hline & & \multicolumn{2}{|c|}{ Domestikasi } & \multicolumn{2}{|l|}{ Pengasingan } \\
\hline & & $\begin{array}{l}\text { Frekuensi } \\
\text { Penggunaan }\end{array}$ & Persentase & Frekuensi Penggunaan & Persentase \\
\hline \multirow[t]{6}{*}{ TT } & Localization & 6 & $40 \%$ & - & - \\
\hline & Preservation & - & - & 4 & $26,67 \%$ \\
\hline & Addition & - & - & 2 & $13,33 \%$ \\
\hline & Transformation & 1 & $6,67 \%$ & - & - \\
\hline & Omission & $\begin{array}{c}0 \\
\text { (2 kali, tapi tidak } \\
\text { dihitung karena } \\
\text { netral) }\end{array}$ & - & $\begin{array}{c}0 \\
\text { (2 kali, tapi tidak dihitung karena } \\
\text { netral) }\end{array}$ & - \\
\hline & Jumlah & 7 & $46,67 \%$ & 6 & $40 \%$ \\
\hline
\end{tabular}


Dari kedua tabel di atas, bisa diketahui bahwa versi terjemahan tersebut memiliki kecenderungan ideologi domestikasi. Dari 15 data, TT atau versi terjemahan Mahbub Djunaidi memiliki 46,67 \% kecenderungan ideologi domestikasi dan $40 \%$ kecenderungan ideologi pengasingan. Versi terjemahan tersebut sebenarnya menggunakan dua kali strategi penerjemahan omission. Namun, karena posisinya berada di antara ideologi domestikasi dan pengasingan, strategi tersebut dianggap netral dan tidak dihitung.

Judul versi terjemahan karya Mahbub Djunaidi diterjemahkan menggunakan localization. Artinya, penulis ingin menunjukkan judul tersebut dalam bahasa Indonesia. Judul tersebut jika diterjemahkan menjadi Binatangisme menunjukkan bahwa '-isme' seakan sama dengan 'farm'. Dalam kamus Cambridge Advance Learner's Dictionary (2008), 'farm' adalah 'an area of land, together with a house and buildings, used for growing crops and/or keeping animals as a business'. Ini mengindikasikan bahwa penulis ingin menjadikan 'farm' sebagai '-isme' yang bersifat ke-Indonesia-an sekaligus mengindikasikan judul tersebut sebagai aliran.

Kata comrades juga diterjemahkan secara menarik oleh Mahbub Djunaidi sebagai 'sahabat-sahabat'. Oleh Bakdi Soemanto (2015), yang masih menerjemahkannya dengan judul Animal Farm, kata tersebut diterjemahkan sebagai 'kamerad'. Kamerad, yang berasal dari kata tovarish, terlihat agak kiri karena identik dengan kaum kiri yang sering menggunakan istilah tersebut. Namun, menurut Fahrurodji (2017), kata tovarish muncul dalam masyarakat borjuis. Tovar berarti komoditas atau barang dagangan. Kata ini muncul ketika orang-orang Rus' kuno menjual dagangan (tovar) di Bizantium. Untuk menghindari adanya perampokan, para pedagang ini memilih bersama. Satu sama lain menyapa dengan sebutan tovarish. Ciri egaliter inilah yang kemudian diteruskan di era Uni Soviet.

Lalu, kenapa istilah kamerad tidak digunakan oleh Mahbub Djunaidi untuk menerjemahkan kata comrades? Kemungkinan karena Mahbub sangat dekat dengan kata tersebut mengingat hubungan akrabnya dengan tokoh-tokoh PKI, salah satunya Nyoto. Judul buku Binatangisme juga merupakan usul dari Nyoto, tapi Mahbub tetap memilih NU sebagai jalannya. Kemungkinan lainnya adalah bahwa Mahbub ingin para 
Ina Mina Saroh, Strategi Penerjemahan Nama Diri dan Kecenderungan Ideologi dalam Versi Terjemahan Novel Animal Farm Karya George Orwell

pembaca menikmati cerita tersebut dengan nyaman-karena kamerad identik dengan paham kiri.

\section{SIMPULAN}

Sejak tahun 1963, novel Animal Farm karya George Orwell telah diterjemahkan beberapa kali ke dalam bahasa Indonesia. Salah satu versi terjemahan di antaranya adalah karya Mahbub Djunaidi. Penerjemah tersebut menggunakan beberapa strategi penerjemahan yang memengaruhi kecenderungan ideologi. Oleh karena itu, strategi penerjemahan nama diri dianalisis dengan menggunakan teori Davies (2003) setelah sebelumnya nama-nama diri dipilih secara acak dengan kategorisasi nama diri dari Frank (1972), yaitu personal names, geographical units, nationalities and religions, holidays, time units, dan words used for personification. Tujuh strategi penerjemahan yang berada di kontinum antara ideologi domestikasi dan pengasingan menurut Davies adalah preservation, addition, localization, omission, globalization, transformation, dan creation.

Dari dua sumber data, yaitu novel Animal Farm dalam bahasa Inggris (ST/Source Text) dan versi terjemahan karya Mahbub Djunaidi (TT/Target Text), diperoleh 15 data yang menunjukkan bahwa versi terjemahan tersebut memiliki kecenderungan ideologi domestikasi. TT atau versi terjemahan Mahbub Djunaidi memiliki 46,67\% kecenderungan ideologi domestikasi dan $40 \%$ kecenderungan ideologi pengasingan. Strategi penerjemahan omission memang dua kali digunakan di TT, tapi frekuensi penggunaan dan persentasenya tidak dihitung karena posisinya berada di antara ideologi domestikasi dan pengasingan (netral). Meski demikian, jika dilihat dari judul keduanya, TT lebih cenderung kepada ideologi domestikasi dengan judul Binatangisme.

Dengan kata lain, bisa disimpulkan bahwa tidak ada karya terjemahan yang cenderung kepada ideologi domestikasi atau pengasingan saja. Kecenderungannya hanya bisa dilihat dari jumlah persentase penggunaan strategi penerjemahan yang mengarah ke ideologi domestikasi atau pengasingan. Akan tetapi, kesimpulan ini hanya 
bersifat asumtif apabila tidak dilengkapi dengan penelitian lanjutan yang datanya lebih representatif.

\section{REFERENSI}

Abdi, H. \& Munandar, A. (2019). The translation of idioms in George Orwell's Animal Farm. Lexicon Volume 6, Number 1, April 2019, 38- 50. https://journal.ugm.ac.id/lexicon/article/download/50307/25776

Arif, A. (2017). Terjemahan satire pada novel Animal Farm. Fakultas Ilmu Bahasa, Universitas

Sumatera

Utara. https://jurnal.unimed.ac.id/2012/index.php/bahas/article/download/12218/105 66

Catford, J.C. (1965). A linguistic theory on translation. London: Oxford University Press.

Baker, M. (2018). In other words: a coursebook on translation. New York: Routledge.

Brislin, R.W.(ed). (1976). Translation: applications and research. New York: Gradner Press.

Davies, E. (2003). A goblin or a dirty nose? treatment of culture-specific references in translations of the Harry Potter books. The Translator: Studies in Intercultural Communication. London: St. Jerome.

Fahrurodji, A. (2017). Dari Druzhba ke Mirnoye Sosushyestvovaniye: diplomasi Uni Soviet-Indonesia dalam era Stalin dan Kruschev 1945-1964. Jurnal Sejarah $\begin{array}{llll}\text { Volume } & \text { I } & \text { (I), }\end{array}$ https://jurnal.masyarakatsejarawan.or.id/index.php/js/article/download/36/39/

Fernandes, L. (2006). Translation of names in children's fantasy literature: bringing young reader into play. New Voices in Translation Studies 2. (P. 44-57). http://citeseerx.ist.psu.edu/viewdoc/download?doi=10.1.1.134.7754\&rep=rep1 \&type $=$ pdf

Fitri, A.A. (2017). A comparative study of idioms translation in two Indonesian translations in George Orwell's Animal Farm. Fakultas Bahasa dan Sastra, Universitas Negeri Jakarta.

Frank, M. (1972). Modern English: a practical reference guide. New Jersey: PrenticeHall, Inc. Englewood Cliffs.

Jaleniauskienè, E \& Čičelytė, V. (2009). The strategies for translating proper names in children's literature. Studies about Languages, No. 15. https://www.kalbos.1t/zurnalai/15_numeris/06.pdf 
Ina Mina Saroh, Strategi Penerjemahan Nama Diri dan Kecenderungan Ideologi dalam Versi Terjemahan Novel Animal Farm Karya George Orwell

Laraswaty, D. (2014). An analysis of domestication and foreignization of cultural words translation in Andrea Hirata's novel entitled Laskar Pelangi. Skripsi, Universitas Pendidikan Indonesia.

Mono, U. (2015). Padanan makna budaya dalam karya sastra: kajian kasus terjemahan novel Animal Farm dalam Bahasa Indonesia. Disertasi, Universitas Sumatera Utara.

Munaf, Y. et al. (2001). Kajian semiotik dan morfologis terhadap tato masyarakat tradisional Kepulauan Mentawai. Jakarta: Pusat Bahasa Departemen Pendidikan Nasional.

Newmark, P. (1988). A textbook of translation. New York: Prentice Hall.

Nida, E. \& Taber, C. (1982). The Theory and Practice of Translation. Leiden: Ej Brill.

Nugroho, A.B. (2015). Strategi penerjemahan nama diri dalam American Indian mithology. Diksi Vol. 23 No. 1 Maret 2015. https://journal.uny.ac.id/index.php/diksi/article/view/6629

Nugroho, A.B. \& Prasetyo, J. (2009). Domestikasi dan foreinisasi dan dampaknya terhadap terjemahan. International Conference on SFL and Its Contributions to Translation Studies, Surakarta, September 23, 2009.

Obeidat, E.S. \& Abu-Melhim, A.R.H. (2017). Foreignisation and domestication in translating English-Arabic baby formula labels. British Journal of Humanities and Social Sciences, September 2017, Volume 17 (2). http://www.ajournal.co.uk/HSpdfs/HSvolume17(2)/HSVol.17\%20(2)\%20Arti cle\%204.pdf

Orwell, G. (1945). Animal farm. UK: Secker \& Warburg.

Orwell, G. (2015). Animal farm (diterjemahkan oleh Bakdi Soemanto). Yogyakarta: Penerbit Bentang.

Orwell, G. 2019. Binatangisme (diterjemahkan oleh Mahbub Djunaidi). Yogyakarta: Gading Publishing.

Parera, J.D. (1986). Kajian linguistik umum historis komparatif dan tipologi struktural. Jakarta: Penerbit Erlangga.

Ratnasari, W, Yuliasri, I, \& Hartono, R. (2016). Technique and ideology of vocatives and proper names in The Hobbit. Journal of Language and Literature XI/I) https://journal.unnes.ac.id/nju/index.php/LC/article/download/7854/5432 
Shandra, E. (2014). Ideological tendency assessed from the translation techniques applied through the proper nouns in Joanne K Rowling's Harry Potter and the Sorcerer's Stone and its bahasa Indonesia translation, Harry Potter dan batu bertuah". Skripsi, Yogyakarta State University.

Sasongko, I. (2003). Pengembangan konsep strukturalisme dari struktur bahasa ke struktur ruang pemikiran. Penelitian Penyusunan Disertasi di Jurusan Arsitektur ITS Surabaya.

Suryarini, Y. (2016). The English translation of proper nouns in Fuadi's Negeri 5 Menara as realized in Kilbane's the Land of Five Towers. Jurnal Bahasa dan $\begin{array}{llllll}\text { Sastra } & \text { Inggris } & \text { Vol. } & 5 & \text { No. } & 1\end{array}$ http://journal.student.uny.ac.id/ojs/index.php/quill/article/view/638

Venuti, L. (2008). The translator's invisibility, a history of translation. London: Routledge.

www.merriam-webster.com/dictionary/farm.

Yan, X.J. (2007). On role of ideology in translation practice dalam US-Chine Foreign Language. Volume 5 No. 4 (serial no. 43) hal 63-65. https://wenku.baidu.com/view/337ca0f9c8d376eeaeaa3148.html?re=view 